\title{
Effects of elevation-dependent climate warming on intra- and inter-specific growth synchrony in mixed mountain forests
}

\author{
Miren del Río ${ }^{\mathrm{a}, \mathrm{b}, *}$, Marta Vergarechea ${ }^{\mathrm{a}, \mathrm{c}}$, Torben Hilmers ${ }^{\mathrm{d}}$, Josu G Alday ${ }^{\mathrm{e}, \mathrm{f}}$, Admir Avdagićc ${ }^{g}$, \\ Franz Binderh $^{\mathrm{h}}$, Michal Bosela ${ }^{\mathrm{i}, \mathrm{j}}$, Laura Dobor ${ }^{\mathrm{k}}$, David I. Forrester ${ }^{\mathrm{l}}$, Velid Halilović ${ }^{\mathrm{m}}$, \\ Aida Ibrahimspahić ${ }^{g}$, Matija Klopcic ${ }^{\mathrm{n}}$, Mathieu Lévesque ${ }^{\mathrm{o}}$, Thomas A. Nagel ${ }^{\mathrm{n}}$, Zuzana Sitkova ${ }^{\mathrm{j}}$, \\ Gerhard Schütze $^{\mathrm{d}}$, Branko Stajić ${ }^{\mathrm{p}}$, Dejan Stojanović ${ }^{\mathrm{q}}$, Enno Uhl ${ }^{\mathrm{d}, \mathrm{h}}$, Tzvetan Zlatanov ${ }^{\mathrm{r}}$, \\ Roberto Tognetti ${ }^{\mathrm{S}}$, Hans Pretzsch ${ }^{\mathrm{d}}$
}

${ }^{a}$ INIA, Forest Research Centre, Crta. La Coruña km 7,5, 28040 Madrid, Spain

$\mathrm{b}$ iuFOR, Sustainable Forest Management Research Institute, University of Valladolid \& INIA, Spain

${ }^{\mathrm{c}}$ NIBIO, Norwegian Institute of Bioeconomy Research, Postboks 155, NO1431 Ås, Akershus, Norway

${ }^{\mathrm{d}}$ Chair of Forest Growth and Yield Science, School of Life Sciences Weihenstephan, Technical University of Munich, Hans-Carl-Von-Carlowitz-Platz 2, 85354 Freising, Germany

e Joint Research Unit CTFC - AGROTECNIO, Av. Alcalde Rovira Roure 191, E25198 Lleida, Spain

${ }_{\mathrm{f}}^{\mathrm{f}}$ Dep. Crop and Forest Sciences, University of Lleida, Av. Alcalde Rovira Roure 191, E25198 Lleida, Spain

${ }^{g}$ University of Sarajevo, Faculty of Forestry, Chair of Forest Management and Urban Greenery, Zagrebačka 20, 71000 Sarajevo, Bosnia and Herzegovina

${ }^{\mathrm{h}}$ Bavarian State Institute of Forestry (LWF), Hans-Carl-von-Carlowitz-Platz 1, D-85354 Freising, Germany

${ }^{\mathrm{i}}$ Faculty of Forestry, Technical University in Zvolen, Slovakia

${ }^{\mathrm{j}}$ National Forest Centre, Forest Research Institute Zvolen, T.G.Masaryka 22, 96001 Zvolen, Slovakia

${ }^{\mathrm{k}}$ Czech University of Life Sciences Prague, Faculty of Forestry and Wood Sciences, Kamýcká 129, 16521 Prague 6, Czech Republic

${ }^{1}$ Swiss Federal Institute of Forest, Snow and Landscape Research WSL, Zürcherstrasse 111, 8903 Birmensdorf, Switzerland

${ }^{\mathrm{m}}$ University of Sarajevo, Faculty of Forestry, Chair of Forest Utilization, Project design and Construction in Forestry and Urban Greenery, Zagrebačka 20, 71000 Sarajevo, Bosnia and Herzegovina

${ }^{\mathrm{n}}$ University of Ljubljana, Biotechnical Faculty, Department of Forestry and Renewable Forest Resources, Večna pot 83, 1000 Ljubljana, Slovenia

${ }^{\circ}$ Forest Ecology, Department of Environmental Systems Science, ETH Zurich, Zurich, Switzerland

${ }^{\mathrm{P}}$ University of Belgrade, Faculty of Forestry, Kneza Višeslava 111030 Belgrade, Serbia

${ }^{\mathrm{q}}$ University of Novi Sad, Institute of Lowland Forestry and Environment, Antona Čehova 13, 21000 Novi Sad, Serbia

${ }^{\mathrm{r}}$ Institute of Biodiversity and Ecosystem Research, Bulgarian Academy of Sciences, 2 Gagarin Street, 1113 Sofia, Bulgaria

${ }^{\mathrm{s}}$ Dipartimento di Agricoltura, Ambiente e Alimenti, Università degli Studi del Molise, Via Francesco De Sanctis, 86100 Campobasso, Italy

\section{A R T I C L E I N F O}

\section{Keywords:}

Species asynchrony

Tree ring

Growth variation

Climate change

\begin{abstract}
A B S T R A C T
Spruce-fir-beech mixed forests cover a large area in European mountain regions, with high ecological and socioeconomic importance. As elevation-zone systems they are highly affected by climate change, which is modifying species growth patterns and productivity shifts among species. The extent to which associated tree species can access resources and grow asynchronously may affect their resistance and persistence under climate change. Intra-specific synchrony in annual tree growth is a good indicator of species specific dependence on environmental conditions variability. However, little attention has been paid to explore the role of the inter-specific growth asynchrony in the adaptation of mixed forests to climate change. Here we used a database of 1790 treering series collected from 28 experimental plots in spruce-fir-beech mixed forests across Europe to explore how spatio-temporal patterns of the intra- and inter-specific growth synchrony relate to climate variation during the past century. We further examined whether synchrony in growth response to inter-annual environmental fluctuations depended on site conditions. We found that the inter-specific growth synchrony was always lower than the intra-specific synchrony, for both high (inter-annual fluctuations) and low frequency (mid- to long-term)
\end{abstract}

\footnotetext{
* Corresponding author at: INIA, Forest Research Centre, Crta. La Coruña km 7,5, 28040 Madrid, Spain.

E-mail addresses: delrio@inia.es (M. del Río), vergarechea.marta@gmail.com (M. Vergarechea), torben.hilmers@tum.de (T. Hilmers), josucham@gmail.com (J.G. Alday), a.avdagic@sfsa.unsa.ba (A. Avdagić), Franz.Binder@lwf.bayern.de (F. Binderh), ybosela@tuzvo.sk (M. Bosela), dobor.laura@gmail.com (L. Dobor), david.forrester@wsl.ch (D.I. Forrester), v.halilovic@sfsa.unsa.ba (V. Halilović), aidaibr@yahoo.com (A. Ibrahimspahić),

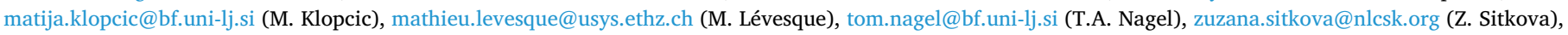
gerhard.schuetze@tum.de (G. Schütze), branko.stajic@sfb.bg.ac.rs (B. Stajić), dejan.stojanovic@uns.ac.rs (D. Stojanović), enno.uhl@tum.de (E. Uhl), tmzlatanov@gmail.com (T. Zlatanov), tognetti@unimol.it (R. Tognetti), hans.pretzsch@tum.de (H. Pretzsch).
} 
growth variation, suggesting between species niche complementarity at both temporal levels. Intra- and interspecific synchronies in inter-annual growth fluctuations significantly changed along elevation, being greater at higher elevations. Moreover, the climate warming likely induced temporal changes in synchrony, but the effect varied along the elevation gradient. The synchrony strongly intensified at lower elevations likely due to climate warming and drying conditions. Our results suggest that intra- and inter-specific growth synchrony can be used as an indicator of temporal niche complementarity among species. We conclude that spruce-fir-beech mixtures should be preferred against mono-specific forests to buffer climate change impacts in mountain regions.

\section{Introduction}

Mountain mixed forests comprised by Norway spruce (Picea abies L.), silver fir (Abies alba Mill.), and European beech (Fagus sylvatica L.) have a substantial share in terms of area in European mountain regions. They cover a broad range of site conditions, altitude, and climates (Hilmers et al., 2019). Although, varying in species proportions this forest type seems to represent a stable forest ecosystem adapted to various growing conditions in mountain areas. But, climate change potentially interferes the current environmental constellation resulting in a shift in productivity, species vitality and competitiveness (Pretzsch et al., 2020a), changing this forest type sustainably. The extent of synchrony in resource acquisition and growth may be relevant for the tree and stand resistance and stability under environmental changes. Synchrony can be understood as the common temporal variation that occurs at different hierarchical levels in an ecosystem, with important implications for ecosystem stability (Wang et al., 2019). In forest ecosystems, analyzing synchrony in growth at different levels can provide important insight into forest dynamics (Tejedor et al., 2020). The rhythm of tree growth can reveal within-tree synchrony or asynchrony in meristem activities and allocation patterns between tree organs (Steinaker et al., 2010), tree-to-tree complementarity in intra- and inter-annual growth patterns (Rötzer et al., 2017), and species specific reactions to stress events (Pretzsch et al., 2013) or climate trends (Pretzsch et al., 2020a). Asynchronous growth rhythms in mixed stands may indicate spatially or temporally complementary resource acquisition and use efficiency (Forrester and Bauhus 2016). This asynchrony can increase stand growth, stand density and stability of stand growth compared with monocultures (Allan et al., 2011; del Río et al., 2017).

However, higher stand density and productivity in mixture does not mean lower competition at the individual tree or species level. In total, there might be more resources captured by trees, but also more trees per unit area competing for limited resources. If one species benefits more from the improved conditions, it may have negative effects on the resource supply and growth of the other species less acclimated to a particular mixture, even triggering species exclusion (Cordonnier et al., 2018). Nevertheless, differences in species growth rates, which shift the competitive balance between species and their abundance in mixed stands, often result in compensatory dynamics that stabilize the community productivity in the long-term (Loreau and de Mazancourt, 2013). When there is a strong environmental driver that synchronizes species growth, compensatory dynamics might be less common (González and Loreau, 2009). Moreover, other factors such as biotic or abiotic disturbances, silvicultural interventions, as well as age and stand structure, can distinctly influence tree growth, which may trigger compensatory dynamics and increase inter-specific asynchrony in the medium-term. Therefore, whether short-term asynchrony between species leads to an increase in their long-term asynchrony may depend on local conditions and species composition.

Growth asynchrony can therefore result from species-specific intrinsic responses to annual environmental fluctuations and to different dynamics independent of environmental fluctuations, such as speciesspecific competitiveness at high densities or responses to disturbances (Loreau and de Mazancourt, 2013). Both components of species asynchrony have been identified as mechanisms of temporal stability of productivity at the stand level, but among them asynchrony in species growth seems to be the main driver (Morin et al., 2014). Therefore, a lower inter-specific than intra-specific growth synchrony might be due to differences in both species' intrinsic response to environmental fluctuations and intrinsic species dynamics, however, species interactions can increase inter-specific asynchrony and contribute to the stabilization of productivity in mixed stands (Morin et al., 2014; del Río et al., 2014, 2017).

Intra-specific synchrony in terms of growth response to inter-annual fluctuations in a stand may be an indicator of tree species dependence on climate variability (Anderegg and HilleRisLambers, 2019). Similarly, inter-specific synchrony may reflect how distinctly or equally the different species respond to this variability. Generally, intra-specific synchrony is greater than inter-specific synchrony due to the different species intrinsic growth responses to climate (Shestakova et al., 2016). When there is a climatic factor strongly limiting growth, greater intraand inter-specific synchronies than under benign conditions could be expected, which means variation in synchrony along spatio-temporal gradients in site conditions (Schurman et al., 2019). Consequently, a number of studies reported an increase in synchrony in tree growth during the last century linked to climate change (e.g. Shestakova et al., 2016; Black et al., 2018). However, studies addressing spatio-temporal patterns of intra- and inter-specific growth synchronies in mixed forests are lacking.

In this study, we explore both intra- and inter-specific growth synchronies within stands of spruce-fir-beech mountain mixed forests, at both high-frequency (inter-annual fluctuations) and low-frequency (mid- to long-term dynamics). Previous analyses of productivity trends in spruce-fir-beech long-term experimental plots in mountain forests of Europe have reported that stand productivity has not changed during the past 30 years (Hilmers et al., 2019). When exploring the temporal trends at the species level, it was found that Norway spruce productivity showed a negative trend, silver fir a positive trend, whereas European beech productivity remained constant. However, at the tree level there was a positive trend for dominant trees of each species during the past centuries, suggesting that climate change had a positive impact on their growth (Pretzsch et al., 2020a). This means that other processes such as mortality and changes in size distribution, more than species competitiveness, are driving the stand level stability and the distinct species trends. Moreover, the two analyses, both at stand and tree level, revealed an important role of elevation on growth, and elevation-dependent tree growth trends for beech and fir.

Our main objective was to explore spatio-temporal patterns of intraand inter-specific growth synchronies in spruce-fir-beech mixed mountain forests across Europe during the last century to better understand the abovementioned growth patterns, and to identify potential short and long-term temporal niche complementarity. Here, we define synchrony as the common inter-annual variability in growth series shared among trees of a given stand. Our specific questions are: i) is intra-specific synchrony higher than inter-specific synchrony in growth response to inter-annual environmental fluctuations and in mid- to long-term growth dynamics?; ii) are synchronies in response to interannual environmental fluctuations and in mid- to long-term growth dynamics correlated?; iii) how do intra- and inter-specific synchronies in growth response to environmental fluctuations depend on site conditions?; and iv) how are synchronies affected by climate change?

According to the abovementioned knowledge and open questions, 
the main hypotheses were: H1: Intra-specific synchrony is higher than inter-specific synchrony in spruce-fir-beech stands. It is valid for synchrony in growth response to inter-annual variation of environmental conditions (high frequency variation), as well as for mid to long-term tree growth dynamics (low frequency variation); H2: A low synchrony in growth response to inter-annual variation in environmental conditions is related to a low synchrony in mid- to long-term growth dynamics; H3: Intra-specific and inter-specific synchronies in response to inter-annual environmental conditions depend on elevation, i.e., synchrony being greater at higher elevations; H4: climate change is increasing synchrony in response to inter-annual environmental conditions, and this increase is greater in intra-specific than in inter-specific synchrony. For testing these hypotheses, we used 1790 tree-ring series from 28 experimental plots in spruce-fir-beech stands distributed across Europe in mountain regions and analyzed them during a 100 years period.

\section{Material and methods}

\subsection{Data}

This study is based on tree-ring data from 28 long-term experimental plots in mixed-mountain forests of Norway spruce, silver fir and European beech. Plots are distributed across six European countries covering the main distribution of this type of mountain forest (Bosnia and Herzegovina, Bulgaria, Germany, Serbia, Slovakia, Slovenia and Switzerland) (Fig. 1). Site elevations range from 621 to $1569 \mathrm{~m}$ a.s.l. Mean annual temperatures and annual precipitation totals during the last century varied from 3.0 to $8.3{ }^{\circ} \mathrm{C}$ and from 796 to $2733 \mathrm{~mm}$, respectively. The three species were well represented in 14 plots, but in 11 plots, fir and beech were the main species, in two plots spruce and fir, and in one plot spruce and beech. The plots represent fully stocked, unthinned or slightly thinned forest stands (for more details of experimental plots see Pretzsch et al., 2020a).

On each plot, two increment cores per tree were collected from about 20 dominant trees of each main species (Table 1). Sampled trees
Table 1

Mean and standard deviation of the number of trees, mean inter-series correlation (Rbar) and expressed population signal by plot and species.

\begin{tabular}{lllll}
\hline Species & $\mathrm{N}^{\circ}$ plots & $\mathrm{N}^{\circ}$ trees/plot & Rbar & \multicolumn{2}{l}{ EPS } \\
\hline Beech & 26 & $27 \pm 14$ & $0.41 \pm 0.16$ & $0.93 \pm 0.05$ \\
Fir & 27 & $26 \pm 13$ & $0.32 \pm 0.16$ & $0.87 \pm 0.11$ \\
Spruce & 17 & $22 \pm 7$ & $0.41 \pm 0.16$ & $0.91 \pm 0.07$ \\
\hline
\end{tabular}

were preferably selected from dominant trees in the buffer zone of the long-term experimental plots in order not to damage the long-term monitored trees. A total of 1790 trees, 706 beech, 702 fir, and 382 spruce trees were used for analysis.

Climate data were compiled for each location covering the study period (1918-2017), including mean annual temperature $\left({ }^{\circ} \mathrm{C}\right)$ and annual precipitation totals $(\mathrm{mm})$. Data from the nearest weather stations were used and corrected for the difference in elevation if the station was far from the plot location. Since observations did not cover the whole period at most of the sites, data were completed using gridded data from the Climatic Research Unit (CRU) Time-Series (TS) Version 3.10 database (Harris et al., 2020). Based on plots geographic coordinates the four closest pixels were selected from CRU, and they were averaged with a weighting by distance. The common period of the two series (observed and CRU series) were used to adjust the CRU series to local conditions.

\subsection{Tree-ring raw data, growth indices, and detrending curves}

Tree ring widths (TRW) were measured to the nearest $0.01 \mathrm{~mm}$ using a digital positioning table (Kutschenreiter and Johann; Digital positiometer, Britz and Hatzl GmbH, Austria). TRW were first visually cross-dated and further verified using the dplR package in $\mathrm{R}$ (Bunn et al., 2020). The mean TRW series for each individual tree was calculated by averaging the annual ring widths from the two cores sampled per tree. For further analysis, the mean TRW series and the common period of the last 100 years were used. Although many TRW

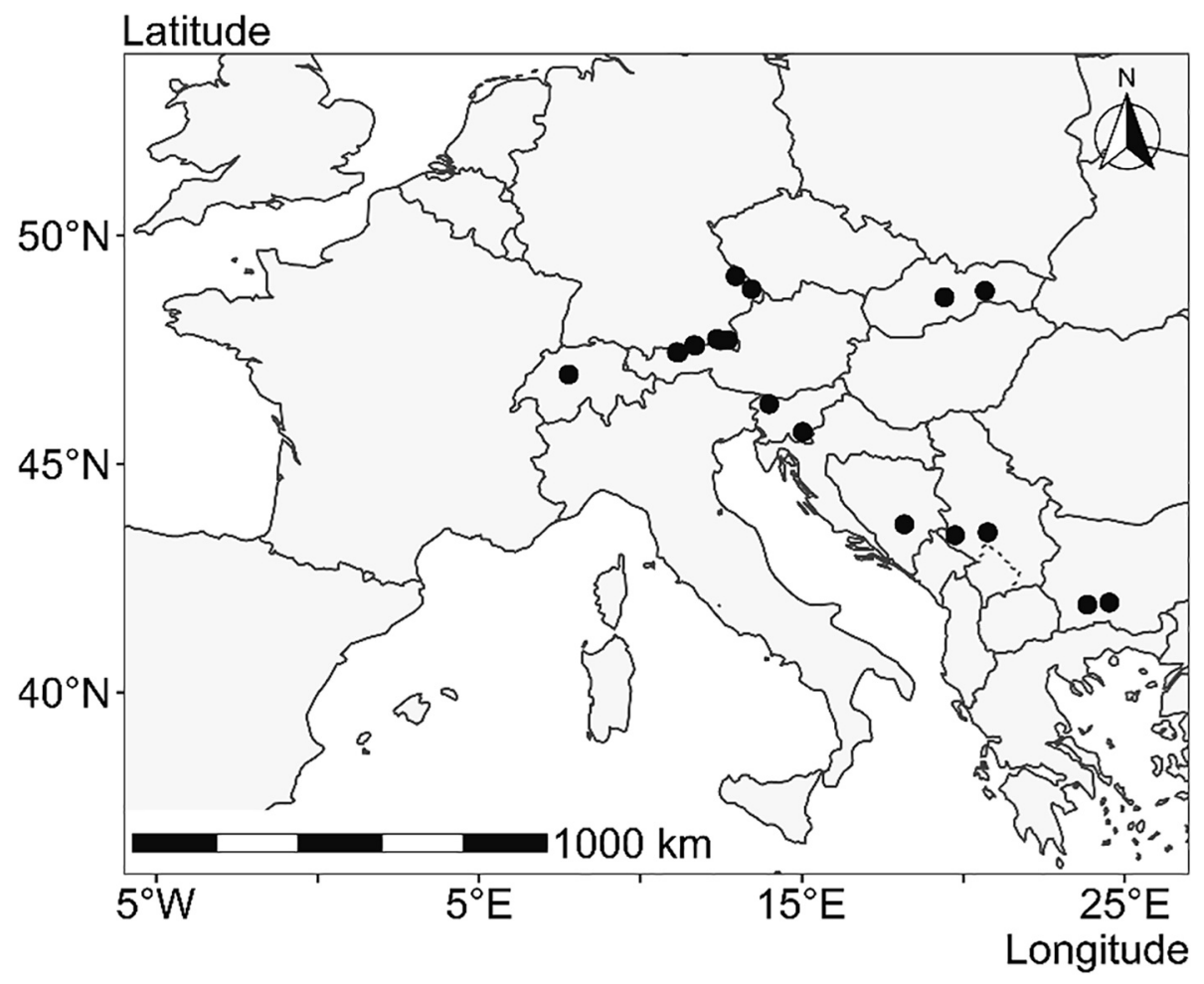

Fig. 1. Location of the long-term experiments used in this study across in Europe. 
series were longer than 100 years, we selected the period from 1918 to 2017, being the common period for most of the series. For each plot, two chronology statistics by species were computed to check the quality of data: the mean inter-series correlation (Rbar) and the expressed population signal (EPS) (Speer 2010). A summary of the statistics by plot and species is presented in Table 1, more details about the site chronologies are provided in Supplementary Table S1.

We tested the first hypothesis (H1) by analyzing the intra- and interspecific synchronies among trees in each plot at three different levels:

i) synchrony in tree-ring raw series $\left(\operatorname{Syn}_{\mathrm{raw}}\right)$, which indicates the $\mathrm{ab}$ solute observed synchrony in stem radial growth;

ii) synchrony in stem radial growth indices or detrended growth series $\left(S_{y} n_{\text {det }}\right)$, which reveals the common signal in high frequency variability linked to the response to inter-annual variation in environmental conditions;

iii) synchrony in detrending curves or low frequency variation $\left(\operatorname{Syn}_{\text {low }}\right)$, which reflects the common signal in other growth pulses or trends linked to competition variation (e.g. disturbances) or low frequency variation in environmental conditions (e.g. sulfur deposition, ozone concentration, climate warming, etc.).

To obtain the detrended dimensionless growth indices, individual TRW series were detrended and standardized through the flexible Friedman supersmoother spline (Friedman 1984). This standardization removed the low frequency common forcing signals in the series. Then temporal autocorrelation in the detrended series was removed by applying a first-order autoregressive model. These two steps to obtain the residual TRW indices were applied using the dplR package in $\mathrm{R}$ (Bunn et al., 2020; R Core Team, 2017). In addition, the detrending spline curves were extracted by the same R package to study the synchrony at the low frequency $\left(\mathrm{Syn}_{\mathrm{low}}\right)$. Supplementary Fig S1 shows an example of the raw TRW series, and resulting series of TRW indices and detrending curves by species of a plot.

\subsection{Synchrony estimation}

In dendrochronological analyses the common interannual variability in stem radial growth series is usually estimated through the mean inter-series correlation (Rbar) (Speer 2010), which is calculated as the average pairwise correlation between series. However, this approach does not consider the associated random structure linked to different time responses at intra or inter-groups levels. Shestakova et al. (2014); (2016;) used a mixed model approach to analyse the spatial patterns of common signal strength of stem radial growth (spatial synchrony) in structured tree ring networks. Here we used their approach to estimate the synchrony or common signal strength of stem radial growth among trees at the stand level, considering the species identity as a grouping factor. In this approach, first mixed models with different variance-covariance (VCOV) structures, including homoscedastic and heteroscedastic versions, were estimated to select the best VCOV structure based on Akaike's Information Criterion (AIC), corrected AIC (AICc) and Bayesian Information Criterion (BIC) (Burnham and Anderson, 2002). Then the intra- and inter-groups synchronies are estimated from the VCOV (for more details see Shestakova et al., 2016: Alday et al., 2018), in our study intra- and inter-specific synchronies. Synchrony values can vary from -1 to 1 . This approach was applied to the three types of tree-ring width growth series (raw, growth indices and detrending curves), obtaining the corresponding synchronies $\left(S y n_{\text {raw }}, S n_{\text {det }}\right.$ and $\left.S y n_{\text {low }}\right)$ for the last century.

To study the trends in synchronies in growth indices $\left(\operatorname{Syn}_{\mathrm{det}}\right)$ during the last century, we estimated moving synchronies in a 30 -years window $\left(\operatorname{Syn}_{\text {det_30y }}\right)$ with a lag of 5 years (Shestakova et al., 2016). All the synchronies were estimated at the plot level using the DendroSync package (Alday et al., 2018, 2019).

\subsection{Statistical analysis}

To test the first hypothesis (H1), differences among intra- and interspecific synchronies were studied through a mixed model (Eq. (1)) for each of the three TRW series (raw, indexd, detrending curves).

$y_{i j}=f($ Composition $)+a_{j}+e_{i j}$

where $y_{i j}$ is the synchrony of the different types of growth indices $\left(S_{y n}\right.$ raw $\left., S n_{\text {det }}, S n_{\text {low }}\right)$ for composition $i$ in the plot $j$; $\mathrm{f}$ (Composition) represents the fixed part of the model depending on the factor composition with six levels of intra-and inter-specific synchronies (B- intrabeech, F- intra-fir, S- intra-spruce, BF- inter-beech-fir, BS- inter-beechspruce, FS- inter-fir-spruce); $a_{j}$ is the parameter linked to the random effect plot, as the annual stem radial growth rates and resulting synchronies for the six compositions in a plot are expected to be correlated. $a_{j}$ and the residual term $e_{i j}$ are assumed to follow a normal distribution with mean zero and variance $\sigma_{\mathrm{a}}^{2}$ and $\sigma_{\mathrm{e}}{ }^{2}$. Then pairwise comparisons were done by the lsmeans R-package (Lenth, 2016).

The Kendall's rank correlation test was applied for analyzing the second hypothesis (H2), i.e. whether there are spatial correlations between the three types of synchronies for each one of the six compositions (e.g. if in the sites where intra-Syn $\mathrm{n}_{\text {raw }}$ for beech is high, the intra$\mathrm{Syn}_{\mathrm{det}}$ is also high or not).

To test the third hypothesis (H3), Eq. (1) was expanded including site conditions (Site_Var) as covariables and using $\operatorname{Syn}_{\mathrm{det}}$ as the dependent variable. Site_Var included climate (mean annual temperature and annual precipitation total) and orographic (e.g. elevation, slope, latitude and longitude) variables, and their interactions with Composition were also tested (Eq. (2)).

$S y n_{\text {detij }}=f($ Compostion, Site_Var $)+a_{j}+e_{i j}$

The fourth hypothesis (H4) was tested in two steps. First, we tested if there were temporal trends in the series of 30-year moving synchronies of growth indices $\left(\mathrm{Syn}_{\mathrm{det} 30 \mathrm{y}}\right)$ during the last century. For this, Eq. (2) was expanded including the 30-year period in the fixed part of the model (Eq. (3)).

Syn $_{\text {det_ } 30 y_{i j k}}=f\left(\right.$ Composition, Site_Var, Period $\left.{ }_{30 y}\right)+a_{j}+e_{i j k}$

Where $\operatorname{Syn}_{\text {det_30yjk }}$ is the $\operatorname{Syn}_{\mathrm{det}}$ for composition $i$ in the plot $j$ and year $k$. Second, we tested if the identified trends were linked to variation in climate conditions (Eq. (4)).

Syn $_{\text {det__30y }}{ }_{i j k}=f($ Composition, Site_Var, Climate $)+a_{j}+e_{i j k}$

As climate variables, we included moving mean temperatures $\left(\mathrm{T}_{\text {mov }}\right)$ and annual precipitation total $\left(\mathrm{P}_{\text {mov }}\right.$ ) using the same window (30 years) and lag intervals (5 years) as those used for $S_{y n} n_{\text {det_ } 30 y}$. To remove the possible effect of the site climates while leaving only the variation during the last century, temperatures and precipitation were standardized by subtracting the mean values for the century $\left(\Delta \mathrm{T}_{\text {mov }}, \Delta \mathrm{P}_{\text {mov }}\right)$. In Eq. (3) and (4) an autoregressive term of order 1 was tested to account for possible temporal dependency among residuals $\left(e_{i j k}\right)$. Models with different independent variables were compared after maximum likelihood (ML) fitting by AIC and the F-test based on the extra sum of squares principle. The selected models were then fitted by restricted maximum likelihood procedure (REML). All models were fitted in $\mathrm{R} \mathrm{v}$ 3.5.1 (R Core Team, 2017) using package 'nlme' (Pinheiro et al., 2020).

\section{Results}

\subsection{Intra- and inter-specific synchronies}

For the three types of synchronies, the intra-specific synchronies were always greater than inter-specific synchronies, corroborating $\mathrm{H} 1$ (Fig. 2). When comparing the different intra-specific synchronies with the inter-specific ones (pair-wise comparisons, Supplementary Table 


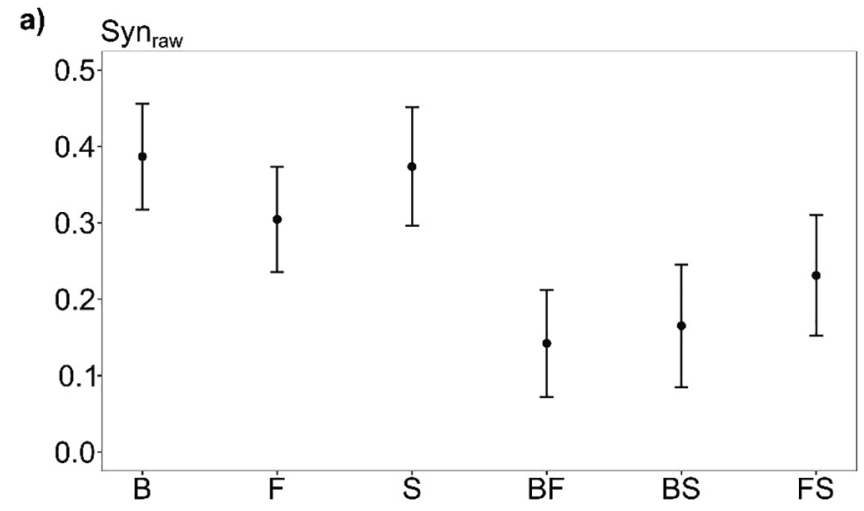

b)

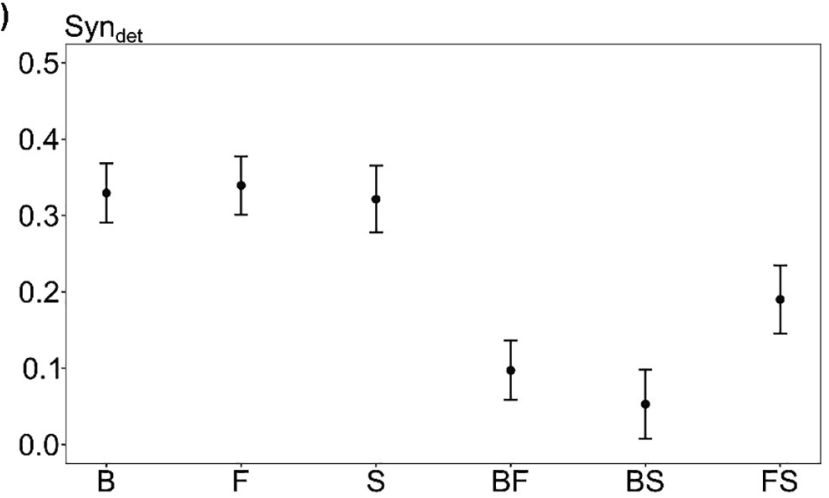

c)

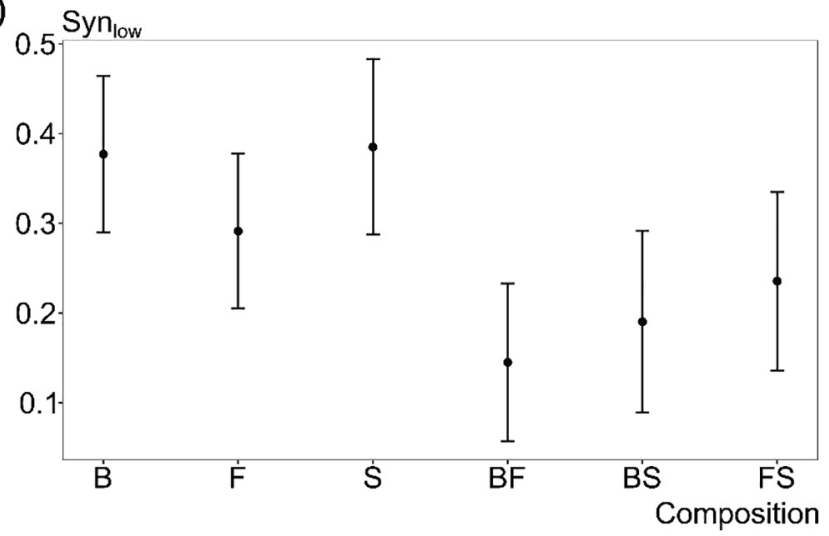

Fig. 2. Predicted means and standard deviation (Eq. (1)) of intra-specific and inter-specific synchronies for (a) tree-ring raw growth series; (b) growth indices; and (c) detrending curves. Intraspecific: B-Beech, F-Fir, S-Spruce: interspecific, BF-between Beech and Fir, BS-between Beech and Spruce, FS-between Fir and Spruce.

S2), the synchrony in raw TRW series was significantly greater except for the comparison intra-Fir (F) and inter-Fir-Spruce (FS) (Fig. 2a). Intra-Syn ${ }_{\text {raw }}$ of beech and spruce showed the highest values. For the TRW indices, the differences between the intra and inter-specific synchronies were larger (Fig. 2b), indicating that species showed different responses to inter-annual variability in growing conditions. The three

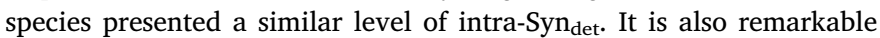
that the inter-Syn $\mathrm{det}_{\text {det }}$ between beech and fir $(\mathrm{BF})$ or beech and spruce (BS) were much smaller (around 0.1) than the one between fir and spruce (Supplementary Table S2). The pattern of the synchronies in detrended curves was similar to that of the tree-ring raw growth series (Fig. 2c), but the differences between the intra- and inter-Syn ${ }_{\text {low }}$ were smaller (Supplementary Table S2).
Table 2

Spatial correlation between the synchronies of the three types of TRW series $\left(S_{y n} n_{\text {raw }}, S_{n_{\text {det }}}, S n_{\text {low }}\right)$ by composition (intra and inter-specific synchronies). Syn ${ }_{\text {raw }^{-}}$Synchrony in tree-ring raw growth series, Syn $_{\text {det }^{-}}$Synchrony in radial growth indices, Syn $_{\text {low }^{-}}$Synchrony in detrending curves, B-Beech, F-Fir, SSpruce.

\begin{tabular}{|c|c|c|c|c|c|c|}
\hline \multirow[b]{2}{*}{ Composition } & \multicolumn{2}{|c|}{ Syn $_{\text {raw }}-$ Syn $_{\text {det }}$} & \multicolumn{2}{|c|}{ 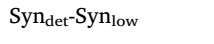 } & \multicolumn{2}{|c|}{ Syn $_{\text {raw }}-$ Syn $_{\text {low }}$} \\
\hline & tau & P-value & tau & P-value & tau & $\mathrm{P}$-value \\
\hline B & 0.206 & 0.1470 & 0.043 & 0.7576 & 0.826 & $<0.0001$ \\
\hline $\mathrm{F}$ & -0.097 & 0.4782 & -0.266 & 0.0524 & 0.807 & $<0.0001$ \\
\hline S & 0.221 & 0.2362 & 0.170 & 0.3430 & 0.923 & $<0.0001$ \\
\hline $\mathrm{BF}$ & 0.099 & 0.4960 & 0.034 & 0.8144 & 0.869 & $<0.0001$ \\
\hline BS & 0.471 & 0.0151 & 0.421 & 0.0292 & 0.919 & $<0.0001$ \\
\hline FS & 0.209 & 0.2699 & 0.185 & 0.3210 & 0.946 & $<0.0001$ \\
\hline
\end{tabular}

\subsection{Correlation between $S y n_{\text {raw }}$, Syn dev and $S y n_{\text {low }}$}

When analysing the spatial correlations between the three types of intra-specific synchronies we found that in most cases the $\operatorname{Syn}_{\text {raw }}$ and $\mathrm{Syn}_{\text {low }}$ were not correlated with $\mathrm{Syn}_{\text {det }}$ (Table 2), even for fir the tau value was negative and close to be significant, indicating that they are responding to different local factors, which contradicts $\mathrm{H} 2$. One exception was beech-spruce synchrony, which was significant, i.e. in plots where $\operatorname{Syn}_{\text {raw }}$ and $\mathrm{Syn}_{\text {low }}$ were high, Syn det was high too. However, the $\mathrm{Syn}_{\text {raw }}$ were strongly correlated to $\mathrm{Syn}_{\mathrm{low}}$, hence expressing the same temporal variation.

\subsection{Dependence on site conditions}

Among the tested site variables, the best model included logtransformed elevation (marginal $\mathrm{R}^{2}=0.69$ ), indicating an increase in synchrony with elevation for all tree compositions (Table 3), in agreement with $\mathrm{H} 3$. The interaction of elevation with the composition was significant (Table 3), with the positive effect of elevation being greater in intra-specific synchrony of beech (Fig. 3).

\subsection{Temporal trends}

The model used to analyse temporal trends in $\operatorname{Syn}_{\mathrm{det}}$, including the moving 30-year period (Eq. (3)), indicated an increase in synchrony during the past century, as stated in $\mathrm{H} 4$, but there was a significant interaction with elevation (marginal $\mathrm{R}^{2}=0.60$, Table 4). The increasing trend was stronger at lower elevations and disappeared at the

Table 3

Parameter estimates for fixed effects, variance components and goodness of fit statistics for Eq. (2), which included the composition and elevation effect. BBeech, F-Fir, S-Spruce, $\mathrm{R}^{2} \mathrm{~m}$ - marginal $\mathrm{R}^{2}, \mathrm{R}^{2} \mathrm{c}$ - conditional $\mathrm{R}^{2}$.

\begin{tabular}{|c|c|c|c|}
\hline Composition & Estimate & Std. Error & $P$ value \\
\hline Intercept (B) & -2.3550 & 0.4637 & 0.0000 \\
\hline $\mathrm{F}$ & 1.3379 & 0.4742 & 0.0059 \\
\hline S & 1.5838 & 0.6066 & 0.0106 \\
\hline $\mathrm{BF}$ & 1.7703 & 0.4851 & 0.0004 \\
\hline BS & 1.0568 & 0.6314 & 0.0977 \\
\hline FS & 1.7479 & 0.6095 & 0.0052 \\
\hline $\ln$ (Elevation) & 0.3895 & 0.0673 & 0.0000 \\
\hline$F^{*} \ln ($ Elevation) & -0.1931 & 0.0688 & 0.0061 \\
\hline$S^{*} \ln ($ Elevation) & -0.2308 & 0.0872 & 0.0096 \\
\hline $\mathrm{BF}^{*} \ln ($ Elevation) & -0.2910 & 0.0704 & 0.0001 \\
\hline BS*ln(Elevation) & -0.1935 & 0.0909 & 0.0361 \\
\hline FS* $\ln ($ Elevation $)$ & -0.2731 & 0.0875 & 0.0025 \\
\hline \multirow[t]{2}{*}{ Random effects } & Plot $\sigma_{\mathrm{j}}$ & 0.0581 & \\
\hline & Residual $\sigma_{\mathrm{ij}}$ & 0.0610 & \\
\hline \multirow[t]{3}{*}{ Fit statistics } & AIC & -226.5337 & \\
\hline & $\mathrm{R}^{2} \mathrm{~m}$ & 0.6926 & \\
\hline & $\mathrm{R}^{2} \mathrm{c}$ & 0.8387 & \\
\hline
\end{tabular}




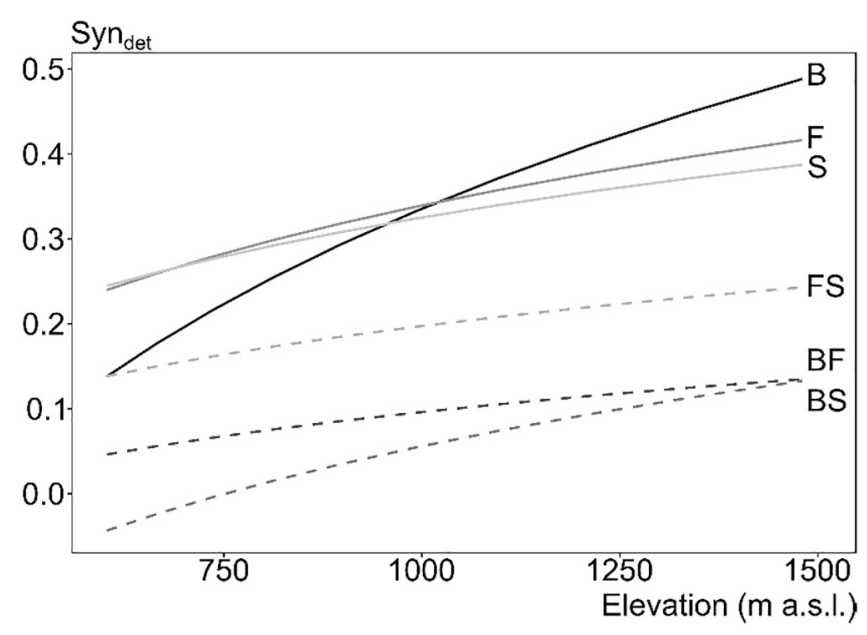

Fig. 3. Effect of elevation on intra- (solid lines) and inter-specific (dashed lines) synchronies of growth indices $\left(\mathrm{Syn}_{\mathrm{det}}\right)$. Intraspecific: B-Beech, F-Fir, S-Spruce: inter-specific, BF-between Beech and Fir, BS-between Beech and Spruce, FSbetween Fir and Spruce.

Table 4

Parameter estimates for fixed effects, variance components and goodness of fit statistics for Eq. (3), which included the effects of composition, elevation and the moving 30-years period during the last century $\left(\right.$ Period $\left._{30 y r}\right)$. B-Beech, F-Fir, S-Spruce, $\mathrm{R}^{2} \mathrm{~m}$ - marginal $\mathrm{R}^{2}, \mathrm{R}^{2} \mathrm{c}$ - conditional $\mathrm{R}^{2}$.

\begin{tabular}{|c|c|c|c|}
\hline Composition & Estimate & Std. Error & $P$ value \\
\hline Intercept (B) & -24.5186 & 8.9736 & 0.0064 \\
\hline $\mathrm{F}$ & 0.8365 & 0.4218 & 0.0475 \\
\hline S & 0.9492 & 0.5370 & 0.0773 \\
\hline $\mathrm{BF}$ & 1.6343 & 0.4242 & 0.0001 \\
\hline BS & 1.6024 & 0.5408 & 0.0031 \\
\hline FS & 1.3993 & 0.5399 & 0.0096 \\
\hline $\ln$ (Elevation) & 3.4190 & 1.2903 & 0.0138 \\
\hline Period $_{30 \mathrm{yr}}$ & 0.0115 & 0.0046 & 0.0114 \\
\hline $\mathrm{F}^{*} \ln ($ Elevation $)$ & -0.1101 & 0.0610 & 0.0712 \\
\hline$S * \ln ($ Elevation $)$ & -0.1277 & 0.0770 & 0.0974 \\
\hline $\mathrm{BF} * \ln ($ Elevation $)$ & -0.2658 & 0.0613 & 0.0000 \\
\hline $\mathrm{BS} * \ln$ (Elevation) & -0.2631 & 0.0776 & 0.0007 \\
\hline FS*ln(Elevation) & -0.2272 & 0.0774 & 0.0034 \\
\hline $\ln \left(\right.$ Elevation)* Period $_{30 \mathrm{yr}}$ & -0.0016 & 0.0007 & 0.0158 \\
\hline \multirow[t]{3}{*}{ Random effects } & Plot $\sigma_{j}$ & 0.0590 & \\
\hline & Residual $\sigma_{i j}$ & 0.0900 & \\
\hline & $\operatorname{AR}(1)$ & 0.7837 & \\
\hline \multirow[t]{3}{*}{ Fit statistics } & AIC & -5153.953 & \\
\hline & $\mathrm{R}^{2} \mathrm{~m}$ & 0.6078 & \\
\hline & $\mathrm{R}^{2} \mathrm{c}$ & 0.7257 & \\
\hline
\end{tabular}

highest elevation ( $\approx 1500 \mathrm{~m}$ a.s.l.) (Supplementary Fig S2). In this model, the interaction between tree composition and elevation was also significant, with a similar effect as in the previous model. However, the interactions between tree composition and the period, although significant, did not improve the model.

When substituting the period effect with climate variables during the past century ( $\left.\Delta \mathrm{T}_{\text {mov }}, \Delta \mathrm{P}_{\text {mov }}\right)$ (Eq. (4)), we found that the increasing trend of synchrony was related to rising temperatures, included in the model by the standardized moving temperatures $\left(\Delta \mathrm{T}_{\text {mov }}\right)$. However, the final model included the three interaction terms (marginal $\mathrm{R}^{2}=0.61$, Table 5): the previously identified interactions between composition and elevation; between composition and $\Delta \mathrm{T}_{\text {mov }}$; and between elevation and $\Delta \mathrm{T}_{\text {mov. }}$. In general, the variation with elevation for the different compositions was similar to previous models, with all the intra-specific synchronies lower than the inter-specific ones. However, the effect of increasing temperatures depended on elevation and tree composition. The effect of increasing temperatures on $S_{y n} n_{\text {det }}$ was much stronger at lower elevations with the exception of intra-specific synchrony of beech, which at low elevations was not affected by changes in temperature (Fig. 4). At higher elevations, where the synchronies are larger, the effect of climate warming was negligible except for intraspecific synchrony of beech, which showed a decreasing pattern with increasing temperatures. It is important to note that temperatures increased during the last century and that this trend did not depend on elevation (results not shown).

\section{Discussion}

In mountain forests climate change impacts are complex, as there can be strong differences on climate conditions on a small elevation zone. In addition, in mixed-species forests growth response to climate can be modulated by species interactions. Through our novel method combining the analysis of intra- and inter-specific growth synchrony at high and low frequency variation we corroborated three of our four hypotheses: H1- we found that intra-specific synchrony was always greater than inter-specific synchrony, suggesting temporal niche complementarity between the species; H3- we identified species-specific and elevation-dependent patterns in both intra- and inter-specific synchronies; and H4-we detected that climate warming is triggering species-specific and elevation-dependent changes in synchrony in tree growth. However, we did not find a general relationship between synchrony in growth response to inter-annual variation in environmental conditions and in mid- to long-term growth dynamics (H2). Although these results, which are further discussed below, are valid for spruce-fir-beech mixed mountain forests in Europe, this approach could be easily applied in other mixed forest ecosystems to unravel signals of climate change impacts and potential temporal niche complementarity between species.

\subsection{Intra- vs. inter-specific synchrony}

In the studied mixed mountain forests, intra-specific synchronies were greater than inter-specific synchronies during the last century, indicating some degree of temporal complementarity between species.

Table 5

Parameter estimates for fixed effects, variance components and goodness of fit statistics for Eq. (4), which includes the effects of composition, elevation and moving standardized temperatures $\left(\Delta \mathrm{T}_{\text {mov }}\right)$. B-Beech, F-Fir, S-Spruce, $\mathrm{R}^{2} \mathrm{~m}$ marginal $\mathrm{R}^{2}, \mathrm{R}^{2} \mathrm{c}$ - conditional $\mathrm{R}^{2}$.

\begin{tabular}{|c|c|c|c|}
\hline Factors & Estimate & Std. Error & $P$ value \\
\hline Intercept (B) & -1.8287 & 0.4338 & 0.0000 \\
\hline $\mathrm{F}$ & 0.9424 & 0.4253 & 0.0268 \\
\hline S & 1.0091 & 0.5402 & 0.0619 \\
\hline $\mathrm{BF}$ & 1.7096 & 0.4277 & 0.0001 \\
\hline BS & 1.6619 & 0.5440 & 0.0023 \\
\hline FS & 1.4602 & 0.5431 & 0.0072 \\
\hline $\ln$ (Elevation) & 0.3071 & 0.0627 & 0.0000 \\
\hline$\Delta \mathrm{T}_{\mathrm{mov}}$ & 0.8531 & 0.2772 & 0.0021 \\
\hline $\mathrm{F}^{*} \ln$ (Elevation) & -0.1249 & 0.0615 & 0.0424 \\
\hline$S^{*} \ln ($ Elevation $)$ & -0.1361 & 0.0775 & 0.0791 \\
\hline $\mathrm{BF}^{*} \ln ($ Elevation $)$ & -0.2763 & 0.0618 & 0.0000 \\
\hline BS*ln(Elevation) & -0.2714 & 0.0781 & 0.0005 \\
\hline FS*ln(Elevation) & -0.2357 & 0.0778 & 0.0025 \\
\hline $\mathrm{F}^{*} \Delta \mathrm{T}_{\mathrm{mov}}$ & 0.1037 & 0.0289 & 0.0003 \\
\hline $\mathrm{S}^{*} \Delta \mathrm{T}_{\mathrm{mov}}$ & 0.0661 & 0.0318 & 0.0381 \\
\hline $\mathrm{BF}^{*} \Delta \mathrm{T}_{\mathrm{mov}}$ & 0.0745 & 0.0293 & 0.0110 \\
\hline $\mathrm{BS}^{*} \Delta \mathrm{T}_{\mathrm{mov}}$ & 0.0711 & 0.0325 & 0.0288 \\
\hline $\mathrm{FS}^{*} \Delta \mathrm{T}_{\mathrm{mov}}$ & 0.0853 & 0.0322 & 0.0083 \\
\hline $\operatorname{Ln}($ Elevation $) * \Delta \mathrm{T}_{\mathrm{mov}}$ & -0.1290 & 0.0399 & 0.0013 \\
\hline \multirow[t]{3}{*}{ Random effects } & Plot $\sigma j$ & 0.0584 & \\
\hline & Residual oij & 0.0902 & \\
\hline & $\operatorname{AR}(1)$ & 0.7859 & \\
\hline \multirow[t]{3}{*}{ Fit statistics } & AIC & -5146.095 & \\
\hline & $\mathrm{R}^{2} \mathrm{~m}$ & 0.6110 & \\
\hline & $\mathrm{R}^{2} \mathrm{c}$ & 0.7260 & \\
\hline
\end{tabular}




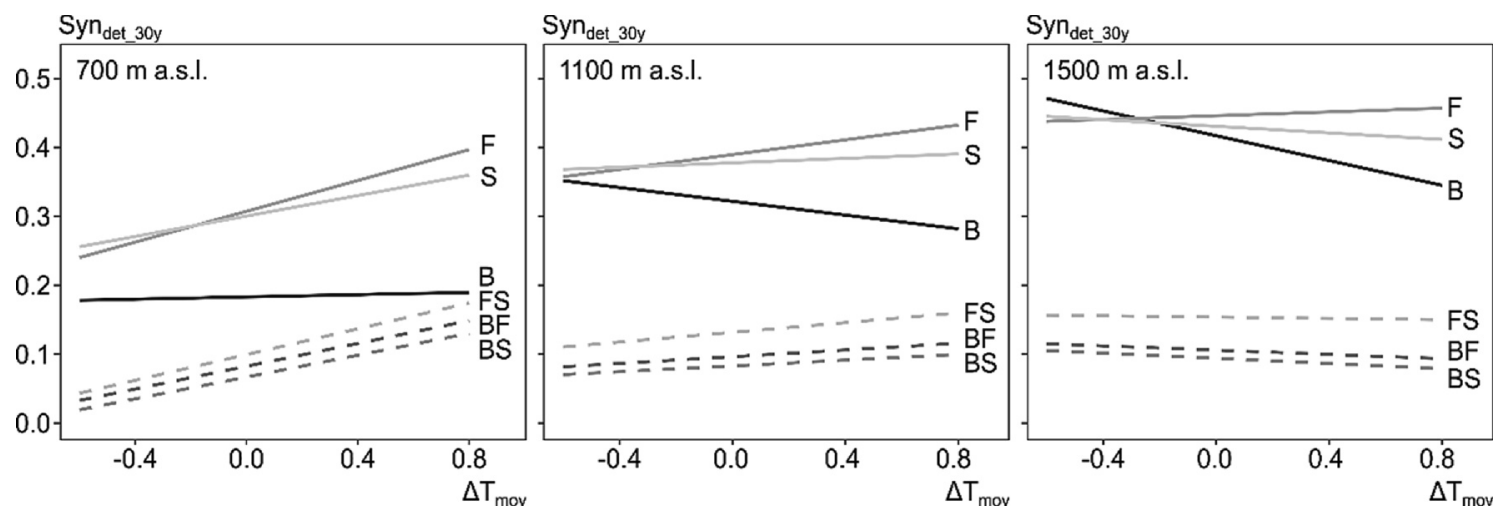

Fig. 4. Predicted effects of moving standardized temperatures $\left(\Delta \mathrm{T}_{\text {mov }}\right)$ at three elevations on intra-specific (solid lines) and inter-specific (dashed lines). Intraspecific: B-Beech, F-Fir, S-Spruce: inter-specific, BF-between Beech and Fir, BS-between Beech and Spruce, FS-between Fir and Spruce.Beech, F-Fir, S-Spruce.

Niche complementarity among species can change in the short-term due to inter-annual climatic variability and in the long-term due to modifications in species demands as stands develop and growing conditions change (Forrester, 2017). Our results suggest the presence of temporal niche complementarity between the three species at both scales, since differences among intra- and inter-specific synchronies were significant

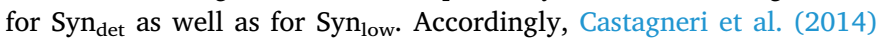
reported that spruce, fir and beech in an old-growth forest showed different climate dependence at both inter-annual and at decadal time scales. However, long-term synchrony can be greatly influenced by competition-driven compensatory dynamics between species (Loreau and de Mazancourt, 2013), i.e. the reduction in abundance or growth of one species is compensated by an increase in other species, which might reduce inter-specific synchrony (or increase asynchrony). Such shifts between species were reported by Hilmers et al. (2019) for spruce-firbeech using a larger data set, including our experimental sites, which could be linked to the observed lower inter- than intra-Syn ${ }_{\text {low }}$.

The mean level of synchronies in the short- and long-term $\left(\operatorname{Syn}_{\mathrm{det}}\right.$ and $\operatorname{Syn}_{\text {low }}$ ) were similar, although the variability of the latter was much larger. This greater variability can be explained by the stronger dependence of species dynamics on stand conditions, such as age, density and stand structure, as well by the stochasticity of disturbances (e.g. Seidl et al., 2011; Mina et al., 2018a; Forrester, 2019).

In any case, the differences between intra- and inter-specific synchronies were larger in $\mathrm{Syn}_{\mathrm{det}}$, suggesting a stronger temporal complementarity in the response to inter-annual environmental fluctuations. It is remarkable that although the three species showed a similar level of dependence on inter-annual climate variation (intra-specific $\operatorname{Syn}_{\mathrm{det}} \approx 0.35$, Fig. $2 \mathrm{~b}$ ), they might depend on different climatic factors since inter-specific $S_{y} n_{\text {det }}$ is rather low, particularly between beech and the two conifers (inter-specific $S_{y n} n_{\text {det }} \approx 0.10$, Fig. 2b). Previous studies reported differentiated inter-annual climatic response of spruce, fir, and beech growing in mixed stands. Although spruce and beech showed different growth reactions to climate (Begović et al., 2020), their growth dependence on climate seems to be more similar than between the two conifers and beech (Castagneri et al., 2014), in agreement with inter-specific $\mathrm{Syn}_{\mathrm{det}}$. Accordingly, belowground niche partitioning between spruce and beech was suggested from the observed different dependence on seasonal precipitation (Allen et al., 2019).

Although our results provide evidence of temporal niche complementarity between all three species, previous studies on competitive interactions in tree growth in spruce-fir-beech mountain forests report mutual positive interactions only for spruce and fir, whereas beech always benefits from growing in this mixture while exerting a stronger competitive effect on spruce and fir (Mina et al., 2018a, 2018b). Forrester et al. (2013) and Forrester and Albrecht (2014) found evidence of niche complementarity between fir and spruce at both below and aboveground levels, which could be related to the lower inter- than intra-specific synchrony observed for $\operatorname{Syn}_{\text {det. }}$ However, the lower interspecific synchrony between beech and the two conifers seems to result in an advantage mainly for beech, probably, as aboveground competition has a high relevance in this mixture (Mina et al., 2018a).

Regarding the spatial correlation between the different types of synchronies, the lack of common patterns at high and low frequencies indicates that they depend on different factors, which in terms of interspecific synchrony means a greater potential for stabilizing stand productivity (Morin et al., 2014). A greater asynchrony between species in response to environmental fluctuations might always increase stability in productivity, and it is expected to be correlated with compensatory dynamics. However, they depend also on other factors (Loreau and de Mazancourt, 2013), as suggested by the lack of spatial correlation between $\mathrm{Syn}_{\mathrm{det}}$ and $\mathrm{Syn}_{\mathrm{low}}$ in our results. One exception is the synchrony between spruce and beech, which indicates that the asynchrony observed in the growth response to interannual environmental fluctuations might also result in asynchronized growth in the long-term, suggesting a strong temporal niche complementarity between these two species (del Río et al., 2014; Pretzsch et al., 2014).

\subsection{Elevation effects}

In mountain areas, temperature is generally the main limiting driver of tree growth, especially at the upper species distribution range (Ettinger et al., 2011). Our results on variation of synchrony in interannual growth fluctuations $\left(\mathrm{Syn}_{\mathrm{det}}\right)$ with elevation agree with this pattern, showing stronger temperature dependence at higher elevations. This pattern was stronger for intra-specific beech $\mathrm{Syn}_{\mathrm{det}}$ than for corresponding fir and spruce synchronies. Elevation is usually related to temperature and the duration of the growing season within the study area (Körner, 2007). Although the three species share an ecological niche in mixed mountain forests, their specific performance varies along elevation ranges. Spruce is more adapted to colder temperatures at higher elevation, while fir, and especially beech, extend their niches at lower elevations with warmer temperatures (Kölling 2007). Beech is also more sensitive to late-spring frost, which is frequent at higher elevations in Central Europe (Dittmar et al., 2006; Vitasse et al., 2019). However, at Mediterranean latitudes other patterns of late-frost damages with elevation were reported for beech, due to delayed phenology at higher elevations (Bascietto et al., 2018).

Accordingly, it is expected that inter-specific synchrony increases with elevation, as climate exerts a stronger control on growth (Jucker et al., 2014). Although at lower elevations the inter-specific synchronies in growth response to inter-annual fluctuations in growing conditions are very low, even negative (asynchrony), the differences between intra- and inter-specific synchrony were larger at higher elevations, which suggests a greater potential impact of temporal niche complementarity between species at the most stressful sites (Paquette and 
Messier 2011). As an example, at the tree line in central Apennines, Calderaro et al. (2020) found an upward shift of mountain pine (Pinus mugo Turra) and European beech, due to global change effects, with facilitative interactions of mountain pine with beech at higher elevation, and competitive interactions at lower elevation.

\subsection{Climate warming effects}

The temporal pattern during the last century found in $\operatorname{Syn}_{\mathrm{det}}$ variability reflects an increasing dependence on climate conditions at lower elevations, where $\mathrm{Syn}_{\mathrm{det}}$ approaches the values found at higher elevations. Our results indicate a link with this temporal pattern to climate warming, in accordance with the climate trends at the study sites (Hilmers et al., 2019), where increasing temperatures but no significant changes in precipitation were observed. Moreover, we found a species-dependence on temperature variation with elevation, with a distinct pattern in beech.

The decreasing intra-specific beech $\operatorname{Syn}_{\mathrm{det}}$ with increasing temperature at higher elevations suggests that the previous limiting effect of temperature at these locations might be significantly reducing by climate warming. This pattern with elevation is consistent with the increase in growth rates of beech observed in the same data set, which was stronger at higher elevations (Pretzsch et al., 2020a) and by Bosela et al. (2018) in fir-beech stands across Europe. For fir, Pretzsch et al. (2020a) report a similar but weaker growth pattern with elevation, but we found no change of synchrony at high elevation (Fig. 4). One possible cause is that in Pretzsch et al. (2020a), a longer period (since 1700) was analysed, whereas our study focuses only on the last century, when fir growth also suffered a decline period due to sulphur deposition (Büntgen et al., 2014). Nonetheless, tree growth trends do not always agree with synchrony trends (Shestakova et al., 2016), as other stand and site characteristics may determine tree growth. For spruce, the direction of elevation pattern of $S n_{\text {det }}$ does not change with climate warming, with greater synchrony at higher elevations, in agreement with the lower growth rates found at such elevations (Pretzsch et al., 2020a). However, the increasing synchrony at lower elevation suggest a stronger dependence on climate at these locations, which could be related to an increase in drought events (Pretzsch et al., 2020b). Schurman et al. (2019) analyzed spruce tree rings during the last century along the Carpathian arc and found a declining effect of elevation on temperature sensitivity but a stronger dependence on moisture at lower elevations, which could explain the increasing $S_{\mathrm{d}} \mathrm{n}_{\mathrm{det}}$ at lower elevation but the lack of change at higher elevation for spruce.

The increasing inter-specific synchronies with climate warming at low elevations but not at high elevations, suggest that climate warming may not affect the stability of this mixture at upper elevation limits, but could be problematic at low elevations, as hypothesized by Pretzsch et al. (2020a) based on tree growth trends. While the main climate driver at high elevations is often temperature, at lower elevations moisture availability is in general more important (Babst et al., 2013). Under drought conditions, species interactions in spruce-fir-beech mountain forests does not seem to increase growth resistance and resilience (Gillerot et al., 2020), which could explain the increasing interspecific $\operatorname{Syn}_{\mathrm{det}}$ at lower elevations. Accordingly, Pretzsch et al., (2018) did not find any mixing effect in spruce and beech response to extreme drought events at low elevation sites.

Nevertheless, inter-specific synchrony remains lower than intraspecific synchrony indicating that some degree of temporal niche complementarity occurs in this mixture. This asynchrony could be triggered by species intrinsic response to climate and/or by species interactions. Recent studies indicate that for mixtures of spruce, fir and beech mixing-effects do not change significantly climate-growth relationships (Bosela et al., 2019; Versace et al., 2020), in agreement with abovementioned studies on tree growth response to extreme droughts, suggesting that species interactions do not play a key role.

\subsection{Methodological considerations}

Synchrony of detrended growth series is considered a good indicator of the common growth response to inter-annual environmental fluctuations, being the basis for dendrochronological analysis (Fritts 1976, Shestakova et al., 2016). Our findings on climate dependence of $\operatorname{Syn}_{\mathrm{det}}$ corroborate that this synchrony can be used as a measure of the environmental stress trees are subjected (Tejedor et al., 2020). However, for a better interpretation of our synchrony results, they should be complemented in a further study with growth-climate analyses, which would allow us to identify which are the main limiting climatic factors of tree radial growth for the three species at different elevations and how they changed during the last century.

Within population synchrony, or in our case within stand synchrony, have been usually estimated through Rbar (e.g. Tejedor et al., 2020). However, when the study aim is to compare synchronies from different groups of a population, using Rbar the possible intra- and inter-group correlation patterns and heteroscedastic errors are not considered. Our synchrony values calculated based on the mixed model framework proposed by Shestakova et al. (2016), provide more robust estimations by testing different VCOV structures.

One limitation of our study is that we use only dominant trees, which can result in biased interpretations as tree growth response to climate vary among crown classes (Cherubini et al., 1998; MartínBenito et al., 2008). This is particularly crucial under climate change with increasing drought events, since growth partitioning among trees can vary from benign to stressful years (Pretzsch et al., 2018). These authors found that for spruce, while in wet years the larger trees benefit more, the growth distribution favors smaller trees during drought years, but the growth partitioning was more or less constant for beech. This suggests that results at the stand level will differ depending on the size distributions and the shape of relationships between tree size and growth (Forrester, 2019), especially considering the frequent positive skewness of size distributions in this mixture (Torresan et al., 2020). The pattern of inter-specific interactions in mixed-species stands may depend on tree size distribution, and in terms of how the inter- and intra-specific differences in tree size contribute to niche separation and complementarity benefits (Forrester, 2019). Considering the frequent positive skewed size distributions in spruce-fir-beech mixtures, sampling in all sizes could result in greater inter-specific asynchrony.

Although inter-specific synchrony of detrending curves of dominant trees $\left(\mathrm{Syn}_{\text {low }}\right)$ cannot be directly interpreted as the synchrony in species dynamics, it might be a good indicator as dominant trees under steady state conditions represent the majority of the stand growth in mixedmountain forests (Magin, 1959, Preuhsler, 1979). Nevertheless, the abovementioned variation in growth-partitioning in the short term, as well as the lack of information about tree mortality, suggest cautiousness when interpreting inter-specific growth synchrony at low frequency variation and highlight the need of further studies at stand level to better understand among species niche complementarity.

\subsection{Concluding remarks}

The approach used in our study, which considers intra- and interspecific growth synchrony, as well as growth synchrony at high and low-frequency variation, provides a powerful tool to identify both between species temporal niche complementarity and climate stress signals. Inter-specific synchrony was always lower than intra-specific synchrony, suggesting between species niche complementarity due to differences in both inter-annual climate dependence and species dynamics.

Climate warming is modifying the strength of growth dependence on climate in spruce-fir-beech mixtures distinctly along elevational gradients. At higher elevations the limiting effect of climate on growth is maintained, or even reduced for beech, while it is intensified at lower elevations, probably by drought. The coherence of growth synchrony 
patterns with previously reported growth trends corroborate that intraspecific synchrony in growth response to inter-annual fluctuations is a good indicator of the climate stress that trees suffer.

Mixtures that increase growth asynchrony at inter-annual and midto long-term scale, such as spruce-fir-beech mountain forests, should be promoted to buffer climate change impacts, as well as other disturbances in mountain environments. This could lead to less risk of abiotic and biotic disturbances, and increased stability of growth and therefore in associated ecosystem goods and services of mountain forests, such as carbon fixation, wood provision, or protection function (soil erosion, avalanches, flooding). Our results indicate that species synchrony is lower between conifers and beech than between the two conifers, highlighting the greater potential of mixtures of species with contrasting traits to stabilize growth. However, we should keep in mind that growth asynchrony and resource partitioning could enhance the depletion of the limited resources during prolonged stressful conditions.

\section{Funding}

This study was supported by the COST Action CLIMO (ClimateSmart Forestry in Mountain Regions - CA15226) financially supported by the EU Framework Programme for Research and Innovation HORIZON 2020. This publication is also part of a project that has received funding from the European Union's HORIZON 2020 research and innovation programme under the Marie Skłodowska-Curie grant agreement No 778322 (CARE4C).

\section{CRediT authorship contribution statement}

Miren del Río: Conceptualization, Methodology, Formal analysis, Writing - original draft. Marta Vergarechea: Formal analysis, Writing review \& editing. Torben Hilmers: Data curation, Writing - review \& editing. Josu G Alday: Formal analysis, Writing - review \& editing. Admir Avdagić: Data curation, Writing - review \& editing. Franz Binderh: Data curation, Writing - review \& editing. Michal Bosela: Data curation, Writing - review \& editing. Laura Dobor: Data curation, Writing - review \& editing. David I. Forrester: Writing - review \& editing. Velid Halilović: Data curation, Writing - review \& editing. Aida Ibrahimspahić: Data curation, Writing - review \& editing. Matija Klopcic: Data curation, Writing - review \& editing. Mathieu Lévesque: Data curation, Writing - review \& editing. Thomas A. Nagel: Data curation, Writing - review \& editing. Zuzana Sitkova: Data curation, Writing - review \& editing. Gerhard Schütze: Data curation, Writing review \& editing. Branko Stajić: Data curation, Writing - review \& editing. Dejan Stojanović: Data curation, Writing - review \& editing. Enno Uhl: Data curation, Writing - review \& editing. Tzvetan Zlatanov: Data curation, Writing - review \& editing. Roberto Tognetti: Writing - review \& editing, Funding acquisition. Hans Pretzsch: Data curation, Writing - original draft.

\section{Declaration of Competing Interest}

The authors declare that they have no known competing financial interests or personal relationships that could have appeared to influence the work reported in this paper.

\section{Acknowledgements}

The authors would like to to thank the Bayerische Staatsforsten (BaySF) for providing the observational plots and to the Bavarian State Ministry of Food, Agriculture, and Forestry for permanent support of the project W 07 'Long-term experimental plots for forest growth and yield research' (\#7831-26625-2017). Furthermore, our work was partially supported by the SRDA via project No. APVV-16-0325 and APVV15-0265, the Ministry of Science and Higher Education of the Republic of Poland, the project "EVA4.0" No. CZ.02.1.01/0.0/0.0/16_019/ 0000803 funded by OP RDE, the Bulgarian National Science Fund (BNSF) via the project No. DCOST 01/3/19.10.2018, the project J41765 funded by the Slovenian Research Agency, and the Ministry of Education, Science and Technological Advancement of Republic of Serbia (877 451-03-68/2020-14/ 200197). J. G.A was supported by the Ramon y Cajal fellowship (RYC-2016-20528). We thank T Shestakova for her useful comments. We finally thank to anonymous reviewers for their constructive criticism.

\section{Appendix A. Supplementary material}

Supplementary data to this article can be found online at https:// doi.org/10.1016/j.foreco.2020.118587.

\section{References}

Alday, J.G., Shestakova, T.A., Resco de Dios, V., Voltas, J., 2018. DendroSync: An R package to unravel synchrony patterns in tree-ring networks. Dendrochronologia 47 (17-22). https://doi.org/10.1016/J.DENDRO.2017.12.003.

Alday, J.G., Shestakova, T.A., Resco de Dios, V., Voltas, J., 2019. DendroSync: A Set of Tools for Calculating Spatial Synchrony Between Tree-Ring Chronologies. R package v (1), 3. https://CRAN.R-project.org/package= DendroSync.

Allan, E., Weisser, W. Weigelt, A., Roscher, C., Fischer, M., Hillebrand, H., 2011. More diverse plant communities have higher functioning over time due to turnover in complementary dominant species. In: Proceedings of the National Academy of Science USA, pp. 17034-17039 10.1073/pnas.1104015108.

Allen, S.T., Kirchner, J.W., Braun, S., Siegwolf, R.T.W., Goldsmith, G.R., 2019. Seasonal origins of soil water used by trees. Hydrol. Earth Syst. Sci. 23, 1199-1210. https:// doi.org/10.5194/hess-23-1199-2019.

Anderegg, L.D., HilleRisLambers, J., 2019. Local range boundaries vs. large-scale tradeoffs: climatic and competitive constraints on tree growth. Ecol. Lett. 22, 787-796. https://doi.org/10.1111/ele.13236.

Babst, F., Poulter, B., Trouet, V., Tan, K., Neuwirth, B., Wilson, R., Carrer, M., Grabner, M., Tegel, W., Levanic, T., Panayotov, M., Urbinati, C., Bouriaud, O., Ciais, P., Frank, D., 2013. Site- and species-specific responses of forest growth to climate across the European continent. Glob. Ecol. Biogeogr. 22, 706-717. https://doi.org/10.1111/ geb.12023.

Bascietto, M., Bajocco, S., Mazzenga, F., Matteucci, G., 2018. Assessing spring frost effects on beech forests in Central Apennines from remotely-sensed data. Agric. For. Meteorol. 248, 240-250. https://doi.org/10.1016/j.agrformet.2017.10.007.

Begović, K., Rydval, M., Mikac, S., Čupić, S., Svobodova, K., Mikoláš, M., Kozák, D., Kameniar, O., Frankovič, M., Pavlin, J., Langbehn, T., Svoboda, M., 2020. Climategrowth relationships of Norway Spruce and silver fir in primary forests of the Croatian Dinaric mountains. Agric. For. Meteorol. 288-289, 108000. https://doi.org/ 10.1016/j.agrformet.2020.108000

Black, B.A., van der Sleen, P., Di Lorenzo, E., et al., 2018. Rising synchrony controls western North American ecosystems. Glob. Change Biol. 24, 2305-2314. https://doi. org $/ 10.1111 / \mathrm{gcb} .14128$.

Bosela, M., Lukac, M., Castagneri, D., et al., 2018. Contrasting effects of environmental change on the radial growth of co-occurring beech and fir trees across Europe. Sci. Total Environ. 615, 1460-1469. https://doi.org/10.1016/j.scitotenv.2017.09.092.

Bosela, M., Kulla, L., Roessiger, J., Seben, V., Dobor, L., Büntgen, U., Lukac, M., 2019. Long-term effects of environmental change and species diversity on tree radial growth in a mixed European forest. For Ecol. Manage. 446, 293-303. https://doi.org/ 10.1016/j.foreco.2019.05.033.

Bunn, A., Korpela, M., Biondi, F., Campelo, F., Mérian, P., Qeadan, F., Zang, C., 2020. dplR: Dendrochronology Program Library in R. R package version 1 (7), 1. https:// CRAN.R-project.org $/$ package $=\mathrm{dplR}$.

Büntgen, U., Tegel, W., Kaplan, J.O., Schaub, M., Hagedorn, F., Bürgi, M., Brázdil, R., Helle, G., Carrer, M., Heussner, K.U., Hofmann, J., Kontic, R., Kyncl, T., Kyncl, J., Camarero, J.J., Willy, T., Esper, J., Liebhold, A., 2014. Placing unprecedented recent fir growth in a European-wide and Holocene-long context. Front. Ecol. Environ. 12, 100-106. https://doi.org/10.1890/130089.

Burnham, K.P., Anderson, D.R., 2002. Model Selection and Multimodel Inference: A Practical Information-Theoretic Approach, second ed. Springer, New York.

Calderaro, C., Cocozza, C., Palombo, C., et al., 2020. Climate-growth relationships at the transition between Fagus sylvatica and Pinus mugo forest communities in a Mediterranean mountain. Ann. Forest Sci. 77, 63. https://doi.org/10.1007/s13595020-00964-y.

Castagneri, D., Nola, P., Motta, R., Carrer, M., 2014. Summer climate variability over the last 250 years differently affected tree species radial growth in a mesic Fagus-Abies-Picea old-growth forest. For. Ecol. Manage. 320, 21-29. https://doi. org/10.1016/j.foreco.2014.02.023.

Cherubini, P., Dobbertin, M., Innes, J.L., 1998. Potential sampling bias in long-term forest growth trends reconstructed from tree rings: A case study from the Italian Alps. For. Ecol. Manage. 109, 103-118. https://doi.org/10.1016/S0378-1127(98)00242-4.

Cordonnier, T., Kunstler, G., Courbaud, B., Morin, X., 2018. Managing tree species diversity and ecosystem functions through coexistence mechanisms. Ann. Forest Sci. 75 (3), 65. https://doi.org/10.1007/s13595-018-0750-6. 
del Río, M., Schütze, G., Pretzsch, H., 2014. Temporal variation of competition and facilitation in mixed species forests in Central Europe. Plant Biol. 16 (166-176). https://doi.org/10.1111/plb.12029.

del Río, M., Pretzsch, H., Ruíz-Peinado, R., Ampoorter, E., Annighöfer, P., Barbeito, I., Bielak, K., Brazaitis, G., Coll, L., Drössler, L., Fabrika, M., Forrester, D.I., Heym, M., Hurt, V., Kurylyak, V., Löf, M., Lombardi, F., Madrickiene, E., Matović, B., Mohren, F., Motta, R., den Ouden, J., Pach, M., Ponette, Q., Schütze, G., Skrzyszewski, J., Sramek, V., Sterba, H., Stojanović, D., Svoboda, M., Zlatanov, T.M., Bravo-Oviedo, A., 2017. Species interactions increase the temporal stability of community productivity in Pinus sylvestris-Fagus sylvatica mixtures across Europe. J Ecol 105, 1032-1043. https://doi.org/10.1111/1365-2745.12727.

Dittmar, C., Fricke, W., Elling, W., 2006. Impact of late frost events on radial growth of common beech (Fagus sylvatica L.) in Southern Germany. Eur. J. Forest Res. 125, 249-259. https://doi.org/10.1007/s10342-005-0098-y.

Ettinger, A.K., Ford, K.R., HilleRisLambers, J., 2011. Climate determines upper, but not lower, altitudinal range limits of Pacific Northwest conifers. Ecology 92 (6), 1323-1331. https://doi.org/10.1890/10-1639.1.

Forrester, D.I., 2017. In: Pretzsch, H., Forrester, D., Bauhus, J. (Eds.), Mixed-Species Forests. Springer, Berlin, Heidelberg 10.1007/978-3-662-54553-9_3.

Forrester, D.I., 2019. Linking forest growth with stand structure: Tree size inequality, tree growth or resource partitioning and the asymmetry of competition. For. Ecol. Manage. 447, 139-157. https://doi.org/10.1016/j.foreco.2019.05.053.

Forrester, D.I., Albrecht, A.T., 2014. Light absorption and light-use efficiency in mixtures of Abies alba and Picea abies along a productivity gradient. For. Ecol. Manage. 328, 94-102. https://doi.org/10.1016/j.foreco.2014.05.026.

Forrester, D.I., Bauhus, J., 2016. A review of processes behind diversity-productivity relationships in forests. Current Forestry Rep. 2 (1), 45-61. https://doi.org/10.1007/ s40725-016-0031-2.

Forrester, D.I., Kohnle, U., Albrecht, A.T., Bauhus, J., 2013. Complementarity in mixedspecies stands of Abies alba and Picea abies varies with climate, site quality and stand density. For. Ecol. Manage. 304, 233-242. https://doi.org/10.1016/j.foreco.2013.04. 038.

Friedman, J.H., 1984. A variable span smoother. Stanford University CA Lab for Computational Statistics, Technical Report, pp. 32.

Fritts, H.C., 1976. Tree rings and climate. Academic Press, London.

Gillerot, L., Forrester, D.I., Bottero, A., Rigling, A., 2020. Lévesque M (2020) Tree Neighbourhood Diversity Has Negligible Effects on Drought Resilience of European Beech. Silver Fir and Norway Spruce. Ecosystems. https://doi.org/10.1007/s10021 020-00501-y.

González, A.B., Loreau, M., 2009. The Causes and Consequences of Compensatory Dynamics in Ecological Communities. Annu. Rev. Ecol. Evol. Syst. 40, 393-414. https://doi.org/10.1146/annurev.ecolsys.39.110707.173349.

Harris I, Osborn TJ, Jones P, and Lister D (2020). Version 4 of the CRU TS monthly highresolution gridded multivariate climate dataset. Scientific Data 7(1): 1-18. Nature Publishing Group. https://doi:10.1038/s41597-020-0453-3.

Hilmers, T., Avdagić, A., Bartkowicz, L., Bielak, K., Binder, F., Bončina, A., Dobor, L., Forrester, D.I., Hobi, M.L., Ibrahimspahić, A., Jaworski, A., Klopčič, M., Matović, B., Nagel, T.A., Petráš, R., del Rio, M., Stajić, B., Uhl, E., Zlatanov, T., Tognetti, R., Pretzsch, H., 2019. The productivity of mixed mountain forests comprised of Fagus sylvatica, Picea abies, and Abies alba across Europe. Forestry 92, 512-522. https:// doi.org/10.1093/forestry/cpz035.

Jucker, T., Bouriaud, O., Avacaritei, D., Coomes, D.A., 2014. Stabilizing effects of diversity on aboveground wood production in forest ecosystems: linking patterns and processes. Ecol. Lett. 17 (12), 1560-1569. https://doi.org/10.1111/ele.12382.

Kölling, C., 2007. Klimahüllen für 27 Waldbaumarten. AFZ-DerWald 23, 1242-1245.

Körner, C., 2007. The use of 'altitude' in ecological research. Trends Ecol. Evol. 22, 569-574. https://doi.org/10.1016/j.tree.2007.09.006.

Lenth, R.V., 2016. Least-Squares Means: The R Package lsmeans. J. Stat. Soft. 69.

Loreau, M., de Mazancourt, C., 2013. Biodiversity and ecosystem stability: a synthesis of underlying mechanisms. Ecol. Lett. 16, 106-115. https://doi.org/10.1111/ele. 12073.

Magin, R., 1959. Struktur und Leistung mehrschichtiger Mischwälder in den bayerischen Alpen. Mitt Staatsforstverwaltung Bayerns 30, 161 p.

Martín-Benito, D., Cherubini, P., del Río, M., Cañellas, I., 2008. Growth response to climate and drought in Pinus nigra Arn. trees of different crown classes. Trees 22, 363-373. https://doi.org/10.1007/s00468-007-0191-6.

Mina, M., del Río, M., Huber, M.O., Thürig, E., Rohner, B., 2018a. The symmetry of competitive interactions in mixed Norway spruce, silver fir and European beech forests. J. Veg. Sci. 29, 775-787. https://doi.org/10.1111/jvs.12664.

Mina, M., Huber, M.O., Forrester, D.I., Thürig, E., Rohner, B., 2018b. Multiple factors modulate tree growth complementarity in Central European mixed forests. J. Ecol. 106, 1106-1119. https://doi.org/10.1111/1365-2745.12846.

Morin, X., Fahse, L., de Mazancourt, C., Scherer-Lorenzen, M., Bugmann, H., 2014. Temporal stability in forest productivity increases with tree diversity due to asynchrony in species dynamics. Ecol. Lett. 17 (12), 1526-1535. https://doi.org/10. 1111/ele.12357.

Paquette, A., Messier, C., 2011. The effect of biodiversity on tree productivity: from temperate to boreal forests. Glob. Ecol. Biogeogr. 20, 170-180. https://doi.org/10 1111/j.1466-8238.2010.00592.x.

Pinheiro J, Bates D, DebRoy S, Sarkar D (2020) R Core Team. nlme: Linear and Nonlinear Mixed Effects Models. R package version 3.1-141. https://CRAN.R-project.org/ package $=$ nlme.

Pretzsch H, Grams T, Häberle KH, Pritsch K, Bauerle T, Rötzer T (2020b) Growth and mortality of Norway spruce and European beech in monospecific and mixed species stands under natural episodic and experimentally extended drought. Results of the KROOF throughfall exclusion experiment. Trees. https://doi.org/10.1007/s00468020-01973-0.

Pretzsch, H., Hilmers, T., Biber, P., Avdagic, A., Binder, F., Boncina, A., Bosela, M., Dobor, L., Forrester, D.I., Lévesque, M., Ibrahimspahic, A., Nagel, T.A., del Rio, M., Sitkova, Z., Schütze, G., Stajic, B., Stojanovic, D., Uhl, E., Zlatanov, T., Tognetti, R., 2020b. Evidence of elevation-specific growth changes of spruce, fir, and beech in European mixed-mountain forests during the last three centuries. Can. J. For. Res. https://doi. org/10.1139/cjfr-2019-0368.

Pretzsch, H., Rötzer, T., Matyssek, R., Grams, T.E.E., Häberle, K.H., Pritsch, K., Kerner, R., Munch, J.C., 2014. Mixed Norway spruce (Picea abies [L.] Karst) and European beech (Fagus sylvatica [L.] stands under drought: from reaction pattern to mechanism. Trees - Struct. Function 28, 1305-1321. https://doi.org/10.1007/s00468-0141035-9.

Pretzsch, H., Schütze, G., Biber, P., 2018. Drought can favour the growth of small in relation to tall trees in mature stands of Norway spruce and European beech. Forest Ecosystems 5, 20. https://doi.org/10.1186/s40663-018-0139-x.

Pretzsch, H., Schütze, G., Uhl, E., 2013. Resistance of European tree species to drought stress in mixed versus pure forests: evidence of stress release by inter-specific facilitation. Plant Biol. 15 (3), 483-495. https://doi.org/10.1111/j.1438-8677.2012. 00670.x.

Preuhsler, T., 1979. Ertragskundliche Merkmale oberbayerischer BergmischwaldVerjüngungsbestände auf kalkalpinen Standorten im Forstamt Kreuth. Forstl Forschungsber München 45, 372.

R Core Team (2017). R: A language and environment for statistical computing. R Foundation for Statistical Computing, Vienna, Austria. URL https://www.R-project. org/.

Rötzer, T., Biber, P., Moser, A., Schäfer, C., Pretzsch, H., 2017. Stem and root diameter growth of European beech and Norway spruce under extreme drought. For. Ecol. Manage. 406, 184-195. https://doi.org/10.1016/j.foreco.2017.09.070.

Schurman, J.S., Babst, F., Björklund, J., Rydval, M., Bače, R., Čada, B., Janda, P., Mikolas, M., Saulnier, M., Trotsiuk, V., Svoboda, M., 2019. The climatic drivers of primary Picea forest growth along the Carpathian arc are changing under rising temperatures. Glob. Change Biol. 25, 3136-3150. https://doi.org/10.1111/gcb.14721.

Seidl, R., Schelhaas, M.J., Lexer, M.J., 2011. Unraveling the drivers of intensifying forest disturbance regimes in Europe. Glob. Change Biol. 17, 2842-2852. https://doi.org/ 10.1111/j.1365-2486.2011.02452.x.

Shestakova, T.A., Aguilera, M., Ferrio, J.P., Gutiérrez, E., Voltas, J., 2014. Unravelling spatiotemporal tree-ring signals in Mediterranean oaks: A variance-covariance modelling approach of carbon and oxygen isotope ratios. Tree Physiol. 34 (819-838). https://doi.org/10.1093/treephys/tpu037.

Shestakova, T.A., Gutiérrez, E., Kirdyanov, A.V., Camarero, J.J., Génova, M., Knorre, A.A., Linares, J.J., Resco de Dios, V., Sánchez-Salguero, R., Volatas, J., 2016. Forests synchronize their growth in contrasting Eurasian regions in response to climate warming. Proc. Natl. Acad. Sci. USA 113 (662-667). https://doi.org/10.1073/pnas. 1514717113.

Speer, J.H., 2010. Fundamentals of tree-ring research. University of Arizona Press.

Steinaker, D.F., Wilson, S.D., Peltzer, D.A., 2010. Asynchronicity in root and shoot phenology in grasses and woody plants. Glob. Chang. Biol. 16, 2241-2251. https://doi. org/10.1111/j.1365-2486.2009.02065.x.

Tejedor, E., Serrano-Notivoli, R., de Luis, M., Saz, M.A., Hartl, C., St George, S., Büntgen, U., Liebhold, A.M., Vuille, M., Esper, J., 2020. A global perspective on the climatedriven growth synchrony of neighbouring trees. Glob. Ecol. Biogeogr. 29 1114-1125. https://doi.org/10.1111/geb.13090.

Torresan, C., del Río, M., Hilmers, T., Notarangelo, M., Bielak, K., Binder, F., Boncina, A., Bosela, M., Forrester, D.I., Hobi, M., Nagel, T.A., Pach, M., Sitkova, Z., Zlatanov, T. Tognetti, R., Pretzsch, H., 2020. Importance of tree species size dominance and heterogeneity on the productivity of spruce-fir-beech mountain forest stands in Europe. For. Ecol. Manage. 457, 117716. https://doi.org/10.1016/j.foreco.2019. 117716.

Versace, S., Gianelle, D., Garfi, V., Battipaglia, G., Lombardi, F., Marchetti, M., Tognetti, R., 2020. Interannual radial growth sensitivity to climatic variations and extreme events in mixed-species and pure forest stands of silver fir and European beech in the Italian Peninsula. Eur J Forest Res. https://doi.org/10.1007/s10342-020-01274-8.

Vitasse, Y., Bottero, A., Cailleret, M., Bigler, C., Fonti, P., Gessler, A., Lévesque, M., Rohner, B., Weber, P., Rigling, A., Wohlgemuth, T., 2019. Contrasting resistance and resilience to extreme drought and late spring frost in five major European tree species. Glob. Change Biol. 25, 3781-3792. https://doi.org/10.1111/gcb.14803.

Wang, S., Lamy, T., Hallett, L.M., Loreau, M., 2019. Stability and synchrony across ecological hierarchies in heterogeneous metacommunities: linking theory to data. Ecography 42, 1200-1211. https://doi.org/10.1111/ecog.04290. 